\title{
The model of voter education of women-based democracy volunteers
}

\author{
Hambali ${ }^{1}$, Hariyanti ${ }^{2}$, Ahmad Eddison ${ }^{3}$ \\ 1,2,3 Civic Education Department, Universitas Riau, Riau, Indonesia
}

\begin{abstract}
This study aimed at describing the model of voter education of women-based democracy volunteers in Pekanbaru City and Dumai City. Democracy volunteers are partners in the General Election Commission, who deliver electoral information to the public. The voter education model consists of the strategies used, the material delivered, the methods used to provide knowledge, raise awareness, and increase women voters' political participation. This research employed a qualitative approach with descriptive methods. The selection of informants in this research is through a non-probability sampling method with a purposive sampling technique. The data validity testing technique used triangulation of data sources. The research findings show that (1) the strategy used was the mapping of target communities and personal communication with community administrators; (2) the material presented included voter requirements, the number of candidates in the 2019 simultaneous elections in Pekanbaru City and Dumai City, introduction of ballot papers, and procedures for voting; (3) the method used was lectures using props in the form of ballots. The female voter is strategic, seeing from the quantity and regulation in Indonesia.
\end{abstract}

\author{
Article History: \\ Submitted : :12-07-2020 \\ Revised : :23-07-2021 \\ Accepted : :13-01-2021
}

Keywords:

voter education model, women-based democracy volunteers, political participation

\section{@) $\odot \odot$}

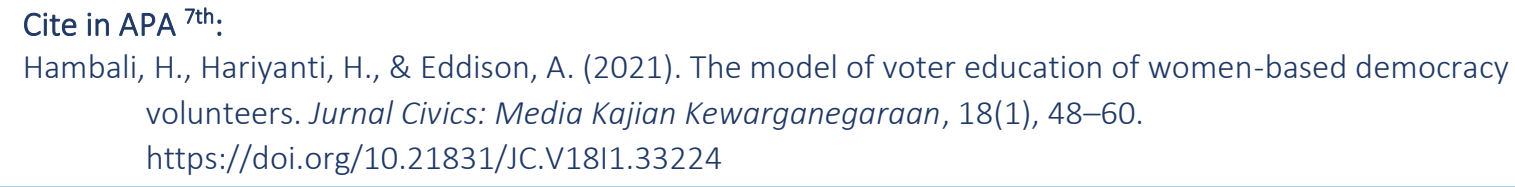

\section{Introduction}

Voter education is a must in a democratic country. General elections are a way for citizens to determine their country/regional leaders' choice for a certain period. A general election's success or failure can be seen quantitatively through the number of citizens' political participation and the quality of general elections that fulfill the principles of direct, general, free, secret, honest, and fair elections. However, the participation rate can be used as an evaluation material regarding the implementation of voter education. This paper was based on the high number of female voters' political participation in Riau Province in the 2019 general election.

Voter education attempts to instill values related to elections and democracy in the nation or country life aimed at citizens who have met voters' requirements in elections or potential voters in the following period. Voter education aims to (1) increase the quality and quantity of citizens' political participation, (2) increase and sharpen political literacy and, (3) foster a voluntary attitude of voters (Manik \& Budhiati, 2015). In short, voter education aims to increase public knowledge and understanding of programs, stages, schedules, processes, and voting procedures in general elections. It also explains the meaning and importance of general elections and citizens' political rights and obligations in Indonesia's democratic country.

Voter education does not only emphasize knowledge about the technicalities of voting but also on how voters can actively participate in elections. Actively participating implies that they can understand the meaning and mechanism of the election to oversee the course of the election. 
This effort will undoubtedly produce smart and responsible voters (Hariyanti, 2015). There are several voter education strategies to achieve this goal, one of which is through the democracy volunteer program.

The democracy volunteer program from now on, referred to as Relasi, is a social movement intended to increase voter participation and quality in using their voting rights. In its recruitment, this program involves the community's participation, where they have a position as pioneers of democracy for their communities. Relasi is motivated by citizens' low political participation in the last four national elections: 1999, 2004, 2014, and 2019 elections. Relasi aims to improve the quality of election implementation, citizen participation, public trust in the democratic system, and foster community volunteerism towards the democratic agenda (KPU, 2019). The existence of Relasi plays an essential role in providing education to the public about elections and democracy on a community-based basis. Thus, it is hoped that the presence of Relasi can increase community participation and political literacy. As innovation in voter education, the Relasi program has been able to play a pivotal role in realizing this goal. At least this effort is reflected in several research results, such as research on the role of democratic volunteers on voter participation in Banggai Laut Regency, where voter participation reached $84.74 \%$ (Sucipto, 2019), and the increase in voter participation rates in the 2019 elections in Bandar Lampung (Alamsyah, 2020), as well as the role of Relasi in conveying political messages in the language that young people preferred towards increasing participation and political literacy of first-time voters (DN et al., 2015; Fauzan, 2017), and also the results of the 2019 election in Riau Province.

Table 1

\begin{tabular}{ccccc}
\multicolumn{5}{c}{ Voter's Political Participation Figures in the 2019 Election in Riau Province } \\
\hline Voter & $\begin{array}{c}\text { Presidential } \\
\text { Election }\end{array}$ & $\begin{array}{c}\text { Regional Representative } \\
\text { Council Election }\end{array}$ & $\begin{array}{c}\text { Regional House of } \\
\text { Representatives } \\
\text { Election }\end{array}$ & $\begin{array}{c}\text { Total of Final Voter } \\
\text { List }\end{array}$ \\
\hline Male & $\begin{array}{c}1,630,377 \\
(49.8 \%)\end{array}$ & $1,624,470(82.74 \%)$ & $1,624,165(82.96 \%)$ & $1,963,287$ \\
Female & $1,624,153$ & $1,635,552(86.08 \%)$ & $1,634,913(85.94 \%)$ & $1,900,018$ \\
\hline
\end{tabular}

(Source: Regional General Election Commission of Riau Province, 2019)

Based on the data above, it is known that the percentage of male voters outperformed female voters. However, in terms of participation, women's political participation rates are higher than men. However, this figure is not directly proportional to the quantity of women's representation in the local legislative body, which has decreased. In the 2014 election, the number of female politicians in the Regional House of Representatives was 18 people, while in the 2019 election, it decreased to 12 people. This study aimed to explore the model of voter education of women-based democratic volunteers to increase female voters' political participation.

Women voters must get voter education because of several considerations: (1) there is still a dichotomy between women and politics (Roza et al., 2014). Politics is perceived as an activity that is cruel, evil, full of competition, and does not match women's characteristics described as gentle, avoiding conflict, and not upholding principles (Novianti, 2008; Predescu \& Darjan, 2010). Politics and political behavior have been seen as masculine behavior (Hariyanti et al., 2018). This perception often leads women to withdraw from political matters, including voting in elections. This perception must be corrected through voter education to women that politics is everyone's business and an essential social aspect of human life because it affects various life areas. Besides, they are also shackled by a gender-biased system (Cardoso et al., 2020); (2) women are still seen as objects in the world of politics. Generally, women voters are loyal and subjective, so they are often the target of pragmatic election contestants (Amin, 2014). Besides women, voters tend to be mobilized to gain support through the labeling of "emak-emak" or "mother of the nation" as in 
the 2014 presidential election, where this labeling reinforces the patriarchal culture in society (Amalia, 2019). (3) Women occupy a strategic position because they have a dual role in the household, namely as wives and mothers for their children. Also, women act as members of particular societies and organizations. Political literacy possessed by women can be an asset in providing political education to those around them (Hariyanti et al., 2018); (4) women voters are not well informed even though they are interested in channeling their voting rights (Sarinastiti \& Fatimah, 2019).

Voter education carried out by Relasi to the female voter base is considered strategic considering several things: (1) Relasi is a national program so that its reach is broad and massive in conveying information related to elections and democracy. The wider the information conveyed, the more female voters will be politically educated; (2) Relasi is a voluntary movement from voters to voters by educating others (in their communities) about the concept of elections and democracy. Information regarding the elections It is expected to be appropriately conveyed through language easily understood by the public. (3) There are many women's associations in society, both formal ones such as Family Welfare Programme (PKK) and Dharma Women's Association (Dharma Wanita), and informal ones such as regular social gathering and reciting the Yaseen. Relasi can come from these groups so that information related to elections and democracy can be digested properly in a relaxed atmosphere.

\section{Method}

This study employed a qualitative-descriptive approach and was conducted on womenbased democracy volunteers in Pekanbaru City and Dumai City. The research instrument is the researcher involved in this research. According to Sugiyono (2017) the human instrument functions to determine the focus of research, select informants as data sources, collect data, assess data quality, analyze data, interpret data, and make conclusions on findings. The sampling technique used was nonprobability sampling, a sampling technique that does not provide equal opportunities for each member of the population to be selected as a sample. A nonprobability sampling includes several sampling techniques. The sampling technique used in this research was purposive sampling, in which the sample was taken by considering specific reasons (Sugiyono, 2017). There are two types of research informants involved in this study. The first one is the Commissioner of Regional General Election Commission of Pekanbaru City and Dumai City, as the party recruiting and evaluating the performance of democratic volunteers. The second one is women-based democracy volunteers, namely voter education facilitators directly involved in educating the public about elections and democracy.

Data collection was carried out through interviews and documentation. Meanwhile, data analysis techniques used the Miles and Huberman model, including data reduction, data presentation, and drawing conclusions and verification. The data validity testing technique employed source triangulation. Source triangulation is used to test the data's credibility by checking the data obtained through several sources. Data collection triangulation techniques were also used by checking the data obtained through several data collection techniques, namely interviews and documentation. The data obtained were then analyzed, described, and categorized (based on similarities, differences, and specifics) from some of these data sources. The data analyzed would produce a conclusion that would then be asked for an agreement (member check) with some of these data sources (Sugiyono, 2017).

\section{Result and Discussion}


Democracy volunteers are a source of information and a role model in delivering information on elections and democracy in a community. Therefore, democracy volunteers play an essential role in building the political literacy of female voters. The research findings show that in implementing voter education for the female voter community, democracy volunteers carry out the following voter education model.

\section{Voter Education Strategies by Democracy Volunteers}

The word strategy comes from Latin, strategia, which means the art of using plans to achieve goals (Anitah, 2007). The voter education strategy is an effort made to instill values related to elections and democracy in a nation or country to citizens who have met the requirements as voters or potential voters later. This effort aims to increase political participation in quantity through voting in elections and quality, such as understanding the importance of elections and democracy. Hence, voters are critical of socio-political issues. The voter education strategy carried out by women-based democracy volunteers is an effort to increase women's political participation. Women become political objects and become subjects who play an essential role in realizing democracy.

The study's findings show that the voter education strategies carried out by women-based democracy volunteers are: (1) mapping female voter groups who are members of a particular community. According to the head of the Pekanbaru City Women's Relasi, the mapping of target groups was not evenly carried out due to several factors, such as a narrow working period, a reasonably large city area. Other fundamental relations could still educate women's groups such as family base, young voters, novice voters, marginalized groups, religious groups, and other groups. The same thing was also expressed by the head of the Women's Relasi in Dumai City, that the mapping was carried out to facilitate Relasi's work in determining the steps to be carried out. Generally, female voters are members of the recitation groups, Family Welfare Programme (PKK), Dharma Women's Association (Dharma Wanita), gymnastics community, and regular social gatherings at levels of the neighborhood (RT), hamlet (RW), or women communities (Dasawisma). However, not everything planned could go as expected because, in the field, it was constrained by inappropriate meeting schedules, so that several community activities were canceled, and not all districts could be visited. Based on the report on women's Relasi activities, the community that is generally targeted is women's recitation groups., the women of Relasi in Dumai City, of the 15 activities carried out, 11 of them were carried out in the recitation group. Meanwhile, in the women-based Relasi activities in Pekanbaru City, out of the 6 activities carried out, one activity was carried out at the recitation program and the other in the gymnastics, regular social gatherings, and Family Welfare Program communities. Suppose we look at other voter bases, especially the family basis. There are similarities in the target community, namely recitation such as family-based relations in Dumai City. Of the six activities carried out, all of them are carried out in recitation groups.

Mapping target communities is one of several voter education strategies as stipulated in the voter education manual and the 2019 Relasi technical manual. Mapping of target groups is seen as capable of smoothing the performance of Relasi to go to the field. At least, Relasi got an overview of the area and target groups. Mapping aims to adjust the schedule of group meetings with the voter education agenda for democracy volunteers and analyze the distribution of groups to be visited in voter education activities because the working area of democratic volunteers is broad, covering cities/regencies of several districts. Ideally, several female voter communities in all sub-districts within Pekanbaru City and Dumai City receive voter education; (c) identify the material appropriate to the target groups that have been defined; (d) prepare accommodation, equipment, and activity equipment. The selection of the dominant target group was carried out in 
the activities of the women recitation group. Presumably, this was done due to several considerations. The first one is the recitation activity, generally attended by many women and is carried out regularly, either weekly or monthly, so that this activity becomes an excellent opportunity to convey information related to elections. Meanwhile, the second one is a recitation group, an informal group, meaning that asking for permission to enter and requesting a time to convey information about the election is not tricky. It is enough to communicate personally with the officials. The recitation group is one of the many local communities found in Indonesia. This community has social capital such as networks because of the close kinship ties among members, values, and norms based on religious teachings that form the community's basis, encouraging them to continue to do good. The recitation group in Indonesia is a non-formal Islamic education institution that has long grown and developed in the community (Neila \& Hidayat, 2017). In its development as a non-formal educational institution, the recitation group has led to a local community that functions as a place to study religion and functions as a forum for economic and socio-political empowerment.

Another strategy is (2) conducting interpersonal communication with target community members. This strategy is carried out to ask community administrators permission to take advantage of the association's activities to carry out voter education activities. This effort implies that target communities' selection is based on the personal acquaintance of democracy volunteers with community officials. Voter education activities by women-based democracy volunteers in Pekanbaru City were carried out six times. The target groups were the Senam Way and Gong Annur Mosque of Pekanbaru, residents of RT 04 Tangkeran Timur of Tenayan Raya Sub-district, members of Family Welfare Program (PKK) of Limapuluh District, members of regular social gathering at RT 01/RW 03 Sukamulya Village of Sail District, the recitation group at Mushola Nurul Jannah of Tuah Madani Village, Tampan District, and the Senam Way and Gong of Tampan District. From these data, only four sub-districts in Pekanbaru City were visited by women-based democracy volunteers. Meanwhile, in Dumai City, women-based democracy volunteers carried out 15 voter education activities. On average, the total activities have spread to almost all districts, except in border areas quite challenging to reach. This strategy is quite helpful because it does not take long to get permission, and voter education activities could also occur. However, this socialization effort is also still hampered by problems related to the limited network of introducing democracy volunteers. This effort will affect the distribution and number of target communities.

Another strategy that Relasi can carry out is through an informal approach to the women around them, such as neighbors and congregations in the mosque. Each democracy volunteer can take an informal approach with casual discussions on the house's terrace or at the mosque while waiting for prayer times. This strategy was carried out personally by volunteers, not in groups like the planned voter education activities. However, this method can be an alternative strategy that is easy to do without spending more money. It is also Relasi's personal responsibility to educate the surrounding community about elections and democracy. However, none of the research informants had this personal approach. They conducted voter education based on the mapping that had been made and implemented with the Relasi team. Ideally, the installation of political knowledge related to elections and democracy is introduced in the immediate environment, such as family and neighbors. After that, the introduction is then continued to peer communities, hobby groups, or other communities since this political knowledge is the embryo that influences one's political participation. According to Surbakti (1999), the factors that influence a person's political behavior are: first, the indirect socio-political environment such as the political system, the economic system, the cultural system, and the mass media. Second, the immediate socio-political environment affects and shapes personality, such as family, religion, school, and social groups. Third, the personality structure is reflected in individual attitudes. In this case, there are three 
operational bases of attitude, namely interest, self-adjustment, externalization, and self-defense. Fourth, the indirect socio-political environment in the form of situations, namely conditions that directly affect individuals when they want to carry out an activity such as weather, family conditions, room conditions, other people, group atmosphere, and various forms of threats. A person's political behavior will be very much determined by the political learning process he receives. Sharp and precise insights are usually obtained from systematic and comprehensive efforts. A person's political behavior, in this case, women's political participation, is determined by the political learning process they receive. The same thing was also expressed that the process of "learning" politics that a person receives will give birth to separate perceptions, and these perceptions will later determine attitudes (Burrell, 2005). Through perception that serves as a filter, a person builds trust and motivation for political stimuli in the real world. Besides, Relasi can also collaborate with academics in higher education to develop the female voter education process because voter education is part of political education that can be carried out by all society levels (Destemi, 2020).

\section{Voter Education Materials for Women-based Democracy Volunteers}

Democracy volunteer is a voluntary movement that aims to increase voters' participation and quality so that Relasi must have knowledge related to elections and democracy that will be conveyed to the public. Based on reports on women's Relasi activities in Pekanbaru City, the material presented during voter education activities was as follows: (1) voter requirements; (2) familiarization of the ballot paper format; (3) procedures for moving voters; (4) the general election methodology; (5) the number of legislative candidates participating in the 2019 elections; (6) as well as consultation and discussion regarding cases that are likely to be encountered during the election. Meanwhile, the Relasi of Dumai City conveyed the following materials: (1) familiarization of ballots; (2) voting procedures; (3) what the 2019 simultaneous election is. The materials presented then provoked various questions from the participants. This situation illustrates the enthusiasm of female voters to learn more about elections and democracy. Based on the interviews with the head of Relasi of Pekanbaru City, it was revealed that, on average, the questions asked by female voters regarding money politics, procedures for moving voters, and the steps that must be taken if not registered in the Final Voters List (DPT).

In the 2019 Relasi Technical Guidelines, voter education materials would be delivered by democracy volunteers had been arranged. The delivered materials were about democracy, general elections, political participation, election time, voting techniques, general election participants, and other matters deemed necessary for the voter base's needs. Based on this arrangement, it looks like the women's Relasi has conveyed the primary material contained in the technical guidelines. However, in terms of creativity, the development of material explicitly related to the target segment was not optimal. As regulated, democracy volunteers are given the freedom to develop materials as long as they strengthen voter skills in utilizing democracy for the public interest (KPU, 2019). The material mastery about politics, democracy, elections, political parties, and participation is a must for Relasi. Good communication significantly affects the message conveyed to be accepted, understood, and implemented by each target group segmentation (Amin, 2014). This statement implies that Relasi must have good political literacy and be accompanied by communication skills easily digested by the public in providing information related to elections.

The materials presented by democracy volunteers regarding elections were still general, and there was no specific material related to the target community. Women base are potential voters in every election because they have many voters and have a high participation rate. However, on the other hand, women's political literacy is still relatively low, women's representation rates are 
stagnant or tend to decline, and women are still seen as political objects. Ideally, democracy volunteers as facilitators have a moral responsibility to provide knowledge about gender and politics, affirmative action regulations in Indonesia, women's representation figures in Indonesia, female figures in Indonesia from the political, socio-cultural, and economic fields, and their roles in the community. Unfortunately, these materials were not provided even though the volunteers were given space to develop and provide appropriate materials to the voter base's needs.

Democracy volunteers could deliver material about gender and politics considering the freedom they have to develop material as long as it strengthens voter skills in utilizing democracy for the public interest. However, this cannot be entirely blamed on volunteers as volunteers recruited from the public. They were not from activists or the electoral community. On average, they worked as teachers in subject areas such as Indonesian, ICT, and sports. Besides, they were housewives, self-employed people, even still students. Generally, they only got briefings once or twice, then given a pocketbook as a guide in providing voter education material in the field. In this pocketbook, the material related to the elections presented was still general.

In Indonesia, the government seeks to boost women's participation in politics. The aim is not only to increase their participation by voting in elections but also to do practical politics such as becoming members of political parties and holding positions as representatives of the people (members of the house representatives) through affirmative action articles. These efforts are embodied in regulations regarding political parties and general elections. However, it seems that these efforts have not been able to achieve the goal. Based on Sali Susiana's research results, it was revealed that regulations regarding affirmative action in Indonesia were not sufficient to increase women's representation in the House of Representatives. These regulations need to complement other rules and policies to increase women's representation rate (Susiana \& Cahyaningrum, 2010). Voter education for women voters through volunteer democracy can be an effort to increase the number of women's representation in the house of representatives because the cognitive orientation, affective orientation, and evaluative orientation of female voters affect their decision to elect female candidates (Nularna, 2017). Delivering material on women's rights and obligations in a democratic country can be essential in women's participation. Furthermore, what women can do when sitting in government for the welfare of women and children, and a big picture of women's situation in various sectors such as the economy, socio-culture, and politics. The position of female democracy volunteers is not to intervene and direct women voters' political choices but to provide knowledge and instill awareness of women's position in society. To some extent, the lack of women's participation is also caused by low political literacy, low awareness of women about their rights, and a patriarchal cultural system (Marzuki, 2006).

The delivery of specific materials related to target communities is entirely dependent on the knowledge, awareness, and creativity of democracy volunteers. Research conducted Fuad (2015) on women's Relasi in Banyumas Regency revealed that other materials provided by Relasi in Banyumas were about the relationship between money politics elections and the mode of money politics that usually occurred during the campaign period. In terms of gender and political issues, the Relasi of Banyumas convinced women's groups to believe that women's representation in parliament would change their fate.

The role of women is currently being considered on all fronts, such as in legal policies, politics, and the social life of a nation, including building an anti-corruption culture that has now become a massive crime front (Azzuhri, 2011). Voter education for women is a strategic matter as a preventive measure to overcome the various problems mentioned earlier. The use of voting rights with careful consideration will create leaders full of integrity. It is based on the rationale that voters will pay attention to the candidate's vision, mission, track record, and personality in 
choosing a candidate for a leader or the house of representative members. This action is a good step, considering women's position in the family, society, and organization circles. Women can be educators in the environment. This statement means that women must take a role in a country or region's political process, starting from small things such as using their voting rights in elections. However, voting is not merely aimed at completing the obligation to vote and, more than that, using voting rights based on political literacy. Indonesian women must be smarter, including in terms of politics, so that they do not only become the objects or materials for exploitation by political contestants to gain votes. Kartini of the $21^{\text {st }}$ century is an independent woman, has characters, is cautious, has advantages and disadvantages, and can interact with others to synergize and complement each other in a harmonious relationship.

Relasi can be a stimulus for affirmative action policies to encourage women's representation in Parliaments. Relasi also convinces women to participate in politics, channels vote in elections and encourages women's political representation in parliament by voting supporting women politicians. If coupled with the awareness to help realize affirmative action policies, the high rate of women's political participation will result in high women's political representation in parliament.

They were providing specific material on gender relations and politics, regulating affirmative action in Indonesia, and motivating women to participate in politics are not forms of volunteer intervention in women's political decisions in making choices. It is because volunteers' position is limited in providing political knowledge that women may not have known due to limited access to information. Volunteers only try to raise women's awareness to participate; the rest depends on the women themselves, whether they are still passive or actively participating. There are at least several reasons why women need to participate in politics; for example, (1) politics is everyone's business. Politics is a dimension present in every human activity and always influences other environments in human life, and politics is a forum for realizing the common good (Surbakti, 1999). Politics is a matter for every individual regardless of gender and gender roles inherent in society's socio-cultural construction. Politics is also a women's affair. Politics is one of the words most talked about by people anywhere and anytime. Each person also defines their scientific background and experience so that politics can be interpreted differently. Everyone could not escape from politics because politics is present in any public space. Politics is a necessity. Politics is concerned with fulfilling obligations, ideology, and insight into public knowledge. Politics is human interaction in the context of power, wherever it is. It is known that power is a relationship that must occur in human interaction wherever they are. In short, political activity occurs wherever and whenever. Everyone cannot escape from political activities, which is why Aristotle stated that humans are zoon politicoon, meaning that human life has a political dimension. Man's political dimension is the dimension of society. Hence, one of the characteristics of an approach called political is that it occurs within a frame of reference oriented towards the community. A decision is called political if it is taken with society's interest in mind. An action must be called political when it concerns society. Politicians are people who have a profession that deals with society.

It should be emphasized here that the politics referred to above mentioned is the political context in terms of voting in elections (narrow meaning) and women's awareness and participation of socio-political problems that occur (in the broad sense). Furthermore, voter education conducted by Relasi is not only about delivering information about elections and encouragement to use voting rights but, broader than that, growing political participation in quantity and quality. In terms of quantity in political participation is like voting at polling stations (TPS), whereas in quality, it is intelligent, rational, and responsible voters. If these efforts have been made, they cannot be easily trapped in money politics, political hoaxes, and black campaigns. 
Meanwhile, political participation is the involvement of citizens in the decision-making process of the government.

Political participation is an activity whereby individuals can play a role in their society's political life (Aidt \& Dallal, 2008). By doing so, they have the opportunity to contribute to outlining the general goals of the community's life and in determining the best means to make it happen (Cascio \& Shenhav, 2020). This effort was made through direct political activities, such as running in general elections, general problematic discussions, participating in political campaigns, or indirect political activities. Surbakti (1999) stated that political participation is the participation of citizens in influencing the process of making and implementing public policies and participating in determining government leaders. Voting in elections is the most obvious form of political participation by citizens. At least this kind of effort reflects citizens' willingness to participate in the political process that affects a country's government's running. Political participation is voluntary on the basis based on initiatives to get involved in political activities (Lundåsen, 2015). It can take the form of involvement in socio-political activities that are carried out periodically, such as voting for general elections, or by using violent acts, or even by subtle means such as political lobbying.

Political participation is a form of citizen rights. This right is explicitly regulated in several articles of the 1945 Constitution. In these articles, it is implied that every citizen has the freedom to express opinions, express thoughts written or orally, and has the right to assemble and associate, including women.

\section{Methods Used by Women-Based Democracy Volunteers}

The method is a way that serves as a tool to achieve a goal. The better the method used, the more effective it will achieve its goals (Anitah, 2007). The voluntary democracy method is a way of conveying election-related information to voters to achieve the voter's education goal, in this case, participating in politics. Voters will participate after absorbing information related to the election given (knowledge), then digesting it (the process towards political awareness) by weighing the merits of the information given to them. If they feel it is following their conscience, it will lead them to participate in actions.

The research findings show that the women's Relasi both in Pekanbaru City and Dumai City used the lecture method and the props in the form of ballots. According to the head of Women's Relasi in Pekanbaru City, this phenomenon occurred because volunteers lacked time to deliver information. It is because voter education activities were carried out on average through target community meetings so that the agenda of voter activities was not the main agenda. The lecture method was deemed appropriate for a large number of participants and the limited time available. Meanwhile, the head of Women's Relasi in Dumai City stated that after the resource person delivered information about the election, participants were then allowed to ask questions. This situation is where feedback occurred between the resource person and the participants.

In the regulations of the General Elections Commission No.8 of 2017 concerning the socialization of general elections for governors and deputy governors, regents and deputy regents, mayors and deputy mayors, the method used in delivering election socialization material is through: (1) citizen forums; (2) face-to-face communication includes discussions, seminars, workshops, work meetings, training, lectures, simulations, talk shows; and/or other face-to-face methods; (3) mass media, including printed and electronic media; (4) socialization materials; (5) social mobilization; (6) utilization of local/traditional culture; (7) the webpages of the General Elections Commission/Independent Election Commission (KIP) of Aceh Province and/or Regency/Municipal; (8) announcement boards for Provincial/ Independent Election Commission 
(KIP) of Aceh Province and/or Regency/Municipal; (9) social media; (10) creative media through arts such as traditional, modern, contemporary arts, music, dance, painting, literature and/or acting; and / or; (11) other forms that make it easier for the public to receive election Information properly. Meanwhile, in the democracy volunteer technical guidelines (2019), the methods used include (1) simulation; (2) role-playing; (3) face-to-face method with group discussion/FGD techniques and (4) lectures; (5) assistive devices (visual and non-visual); (6) posting socialization materials to the media. Based on the previously mentioned findings, it appears that democracy volunteers only focused on one method, the lecture method using props in the form of ballots.

Apart from using conventional methods that lead to one-way communication, other methods are needed. One method that is deemed suitable for coaching to change or shape behavior includes positive reinforcement, which attempts to strengthen a behavior to repeat the behavior. This strengthening is done by giving something fun or rewarding to the organization's members (Badeni, 2014). Providing rewards for voter education participants who actively ask questions during the activity is an example of this positive reinforcement.

Besides, the simulation method can also be an alternative to other methods that can be used to educate voters about the flow of voting at polling stations. Simulation means doing something that is pretended as if it happened. This simulation is done to provide an accurate picture of the actual action/event. In female voter education activities, a simulation method can be provided in the form of a simulation of how a black campaign occurs and how this affects voters. Democracy volunteers must carry attributes such as banknotes, a replica of basic daily needs, or items used to influence voters to vote for a particular candidate. Democracy volunteers explain the types of black campaigns and simulate them, such as providing daily needs and money to ask voters to vote for one candidate. Democracy volunteers determine the roles to be played, the arrangement of tools, the selection of role holders, and information about the roles to be performed. Here volunteers can ask the willingness of female voters to act as voters who will be influenced. The simulation method can provide knowledge and understanding by imitating actual practices in the field. The voting they do in elections becomes the political participation with high quality and avoiding fraudulent practices that tarnish the democratic political system. This practice means that political participation is carried out purely as a form of voluntary action by citizens to change leaders based on personal awareness.

The voter education model used by democracy volunteers in Pekanbaru City and Dumai City has been proven to contribute to the high number of female voters' political participation. The final voter list (DPT) in the 2019 elections in Riau Province was 3,863,305 votes. The number of male voters was 1,963,287 votes, while the number of female voters was 1,900,018 votes. In terms of participation, women's political participation rates are much higher than men. In the 2019 Presidential Election, women's political participation rate was $50.2 \%$, while for men, it was $49.8 \%$. In the Regional Representative Council elections, the female political participation rate was 86.08\%, while the male figure was $82.74 \%$. Then in the 2019 Regional House of Representatives elections, women's political participation rate was $85.94 \%$, while it was $82.96 \%$ for men. However, when viewed from the quantity of women's representation in the regional parliament, it has decreased. In the 2014 election, the number of female politicians in the Regional House of Representatives was 18, while in the 2019 election, it decreased to 12 (Riaupos.com). However, despite these successes, strategies, materials, and other methods are needed based on the recommendations of this study's results, bearing in mind that there are still some shortcomings in implementing female voter education. The recommended models for women's relations are as follows. 
Models for Women's Relations

\begin{tabular}{cccc}
\hline No. & Strategy & Material & Method \\
\hline 1. & Mapping of target & Gender and politics & Positive reinforcement \\
2. & Interpersonal & Indonesian female figures, regulations of \\
& communication with & affirmative action in Indonesia, description of \\
& administrators & Indonesian women's political participation & \\
3. Informal Approach & Money politics, political hoaxes, and black \\
& & campaigns & \\
\hline
\end{tabular}

\section{Conclusions}

Voter education exists in a democratic country like Indonesia. Citizens must be educated in various ways. Democracy volunteers are here to answer voters' need for knowledge about elections. The voter education model used by women-based democracy volunteers in Pekanbaru City and Dumai City is concluded. The first strategy undertaken was mapping the target community and interpersonal communication with target community boards. This strategy can gather several communities with many participants, averaging 50-100 people in one voter education activity. The second is the material presented included voter requirements, introduction to ballot paper formats, procedures for moving to elect, how to conduct general elections, voting procedures, the definition of simultaneous elections in 2019, and the number of legislative candidates participating in the 2019 elections. Another essential requirement is consultation and discussion regarding cases that are likely to be encountered during the election. These requirements are the raw materials that have been regulated in the 2019 technical guidelines of Relasi and what participants get about debriefing/training. In general, it can be said that the material conveyed by relations is information that is very much needed by the community considering the massive money politics and political hoaxes ahead of the election. With the existence of Relasi, voters become enlightened with valid information and can be a motivation for voters to participate; (3) the method used was lecturing using teaching aids. This method was deemed appropriate for many participants and the limited time available. The voter education model used by democracy volunteers in Pekanbaru City and Dumai City has been proven to contribute to the high number of female voters' political participation. However, further research is needed on whether women voters use their voting rights to act intelligently, rationally, and responsibly.

\section{Acknowledgement}

The researchers expressed their gratitude to the Dean of the Faculty of Teacher Training and Education, University of Riau, who had funded this research. Furthermore, thanks to the research team who helped in the research process and writing this article.

\section{References}

Aidt, T. S., \& Dallal, B. (2008). Female voting power: The contribution of women's suffrage to the growth of social spending in Western Europe (1869-1960). Public Choice, 134(3-4), 391417. https://doi.org/10.1007/s11127-007-9234-1

Alamsyah, A. (2020). Peran relawan demokrasi dalam meningkatkan partisipasi pemilihan umum 2019 (Studi kasus di Kota Bandar Lampung). Universitas Lampung.

Amalia, L. S. (2019). Upaya mobilisasi perempuan melalui narasi simbolik 'emak-emak dan ibu bangsa' pada pemilu 2019. Jurnal Penelitian Politik, 16(1), 17-33. https://doi.org/10.14203/jpp.v16i1.779 
Amin, M. (2014). Relasi relawan demokrasi dan pemilih pada pemilu tahun 2014. In Pembekalan Peran Serta Relawan Demokrasi dalam Usaha Meningkatkan Partisipasi Pemilih pada Pemilu 2014. KPU Medan.

Anitah, W. S. (2007). Strategi Pembelajaran. Universitas Terbuka.

Azzuhri, M. (2011). Pemberdayaan perempuan dalam membangun budaya anti korupsi. Muwazah, 3(2), 466-472. http://ejournal.iainpekalongan.ac.id/index.php/Muwazah/article/view/270/241

Badeni. (2014). Kepemimpinan dan perilaku organisasi. Alfabeta.

Burrell, B. C. (2005). Gender, presidential elections and public policy: Making women's votes matter. Journal of Women, Politics and Policy, 27(1-2), 31-50. https://doi.org/10.1300/J501v27n01_03

Cardoso, M., Mendes, R. S., Souza, J. T. G., \& Ribeiro, H. V. (2020). Gender difference in candidature processes for Brazilian elections. Physica A: Statistical Mechanics and Its Applications, 537(January), 1-7. https://doi.org/10.1016/j.physa.2019.122525

Cascio, E. U., \& Shenhav, N. (2020). A Century of the American Woman Voter: Sex gaps in political participation, preferences, and partisanship since women's enfranchisement. Journal of Economic Perspectives, 34(2), 24-48. https://doi.org/10.1257/jep.34.2.24

Destemi, S. (2020). Pendidikan politik perempuan dalam menghadapi pemilihan kepala daerah Provinsi Jambi tahun 2020. Seminar Nasional Pemberdayaan Masyarakat, Pekanbaru, 2(ISSN 2685-9017), 11-19.

DN, S., Soeprapto, A., \& Suparno, B. A. (2015). Relawan demokrasi sebagai komunikator politik bagi pemilih pemula. KNK ISKI, 5, 11-13.

Fauzan, N. (2017). Pedagogi pemilu dan demokrasi (Studi di pusat pendidikan pemilih KPU Kota Bandar Lampung). universitas brawijaya.

Fuad, Z. M. (2015). Peran pemuda relawan demokrasi dalam meningkatkan partisipasi politik masyarakat pada pemilihan umum legislatif tahun 2014 dan implikasinya terhadap ketahanan politik wilayah (studi pada relawan demokrasi Banyumas, Jawa Tengah). Jurnal Ketahanan Nasional, 21(1), 23-33. https://doi.org/10.22146/jkn.6891

Hariyanti. (2015). Pelaksanaan pendidikan pemilih melalui kerjasama KPU Kota Padang dengan MGMP PKn SMA/MA Kota Padang. Universitas Negeri Padang.

Hariyanti, Darmawan, C., \& Masyitoh, I. S. (2018). Peran partai politik dalam meningkatkan partisipasi politik kader perempuan melalui pendidikan politik. Jurnal Civics: Media Kajian Kewarganegaraan, 15(1), 74-85. https://doi.org/10.21831/jc.v15i1.17659

KPU. (2019). Pedoman pelaksanaan relasi pemilu tahun 2019. Komisi Pemilihan Umum Republik Indonesia.

Lundåsen, S. W. (2015). Civil society and political participation: What type of political participation is influenced by community level involvement in civil society? Swiss Political Science Review, 21(1), 140-157. https://doi.org/10.1111/spsr.12140

Manik, H. K., \& Budhiati, I. (2015). Pedoman pendidikan pemilih. Komisi Pemilihan Umum Republik Indonesia. 
Marzuki, M. (2006). Kekerasan terhadap perempuan dalam wacana tafsir keagamaan di Indonesia perspektif Islam. Jurnal Civics: Media Kajian Kewarganegaraan, 3(2), 67-77. https://doi.org/10.21831/civics.v3i2.5746

Neila, \& Hidayat. (2017). Pemberdayaan kelompok pengajian perempuan berbasis modal sosial di Kota Medan. Jurnal Antropologi Sumatera, 15(1), 259-269.

Novianti, I. (2008). Dilema kepemimpinan perempuan dalam islam. Yinyang: Jurnal Studi Islam Gender

Dan Anak, 3(2),

255-261. http://ejournal.iainpurwokerto.ac.id/index.php/yinyang/article/view/202

Nularna, P. (2017). Orientasi politik pemilih perempuan dan keputusan memilih. Jurnal Demokrasi Dan Otonomi Daerah, 15(1), 25-30. https://jdod.ejournal.unri.ac.id/index.php/JDOD/article/view/5228

Predescu, M., \& Darjan, I. (2010). Promoting political participation through adult education. Procedia - Social and Behavioral Sciences, 2(2), 3241-3245. https://doi.org/10.1016/j.sbspro.2010.03.495

Roza, V., Rodríguez-Tejedo, I., Silva, A. M., Cruz, Y., \& Vega, G. (2014). Women's voter mobilization campaign in Guatemala: A field experiment.

Sarinastiti, N., \& Fatimah, P. S. (2019). Edukasi komunikasi politik dalam menciptakan kesadaran dan minat pemilih perempuan. Jurnal Kajian Komunikasi, 7(1), 44-58. https://doi.org/10.24198/jkk.v7i1.19125

Sucipto, D. (2019). Peran relawan demokrasi dalam meningkatkan partisipasi pemilih pada pemilihan umum tahun 2019 (Studi di Komisi Pemilihan Umum Kab. Banggai Laut). Jurnal Yustisiabel, 3(2), 213-229. https://doi.org/10.32529/yustisiabel.v3i2.399

Sugiyono. (2017). Metode penelitian kualitatif. Alfabeta.

Surbakti, R. (1999). Memahami ilmu politik. Gramedia Widiasarana Indonesia (Grasindo).

Susiana, S., \& Cahyaningrum, D. (2010). Implementasi pasal tentang affirmative action dalam Undang-Undang Nomor 10 Tahun 2008 tentang Pemilu Anggota DPR, DPD, Dan DPRD (Studi di Provinsi Maluku Utara). Kajian, 15(1). https://doi.org/10.22212/kajian.v15i1.382 